Type of the Paper (Article, Review, Communication, etc.)

\title{
Reduction of Antibiotic residue in milk through the use of cost effective Ethno-Veterinary Practices (EVP) for cattle health management
}

\section{Balakrishnan M N Nair, Punniamurthy N. and Kumar, S. K.}

Center for Ethno-veterinary Science and Practice, The University of Trans-disciplinary Health Sciences and Technology (TDU), Jarakabandekaval, Attur post, Yelahanka, Bangalore, 560064, India, Communicating author: email - nair.mnb@tdu.edi.in

Abstract: This study demonstrated that antibiotic residue in milk can be reduced when dairy farmers use Ethno-veterinary Practices (EVP) based on herbal alternatives to prevent and cure common clinical conditions in cattle instead of antibiotics. Of the 220 farmers selected for the study, 140 were trained and motivated to use validated herbal formulations, 80 were kept as control. Milk samples from the selected farmers (except Thirukanurpatti milk society) tested positive for antibiotic residue in the baseline survey. One year after interventions, the milk from $123(87.86 \%)$ farmers out of 140 , were without any detectable antibiotic residue, while samples from 11 farmers $(7.85 \%)$ were low positive for either Beta-lactams or sulphonamides and $6(4.29 \%)$ were positive for Beta lactams and/or sulphonamides. These $17(11+6)$ farmers had used antibiotics along with herbal formulations. The milk samples from the control groups were positive for beta lactam and sulphonamide. There was suggestive significance of change in knowledge, attitude and practice of EVP among the farmers from Kerala and Tamil Nadu. A progressive reduction in the incidence of mastitis, enteritis, repeat breeding and cowpox were observed from 2016 to 2019 among the cows treated with EVP. Use of herbal alternative also resulted in a significant reduction in health care expenditure of cattle.

Keywords: Antibiotics residue; Antimicrobial resistance; Ethno-veterinary practices; Herbal formulations; cattle health; dairy farmers; cost effective health care model

\section{Introduction}

There are many reports of antibiotic residues in milk [1-12]. It also causes side effects and allergic reactions on people who consume animal products such as milk and meat [13-18]. In many countries AMR is a threat to public health and the world is looking for safer alternatives through herbs. It is also predicted that the global consumption of antimicrobials will go up to $67 \%$ from 2010 to 2030 [16, 18, and 20]. Tackling a Crisis for the Health and Wealth of Nations was published on the request of the UK Prime Minister to address the growing global problem of It is predicted that drug-resistant infections will kill an extra 10 million people a year worldwide by 2050 and the total cost of antimicrobial resistance on world Gross Domestic Product (GDP) will be $\$ 100$ trillion [17, 21]. One of the immediate challenges to reduce AMR is to limit the use of antibiotics in human and animal health management. As the antibiotic residues finding their way into the food chain, there is an urgent need to focus on reducing the use of antibiotics in veterinary practice. With limited or no strategic implementation of regulatory policy on controlling the 
misuse of antibiotics in dairy sector in India, the focus needs to be shifted to work with farmers, animal keepers and veterinarians in identifying approaches and options to use ethno-veterinary practices based on natural plant products to control microbial diseases. There are reports on the documentation of ethno-veterinary practices from several parts of India [22-44]. Ethno-veterinary medicine has also been suggested as alternative to antibiotics [14, 15, and 20]

The University of Trans-disciplinary Health Sciences and Technology (TDU) along with Tamil Nadu Veterinary and Animal Sciences University (TANUVAS) have documented Ethno-veterinary practices from 24 locations in 10 states of India and rapidly assessed them using Ayurveda and established that 353 formulations out of 441 are safe and efficacious [39] There are reports of validation of herbal formulations for Mastitis [40-43] and reduction of retention of placenta (ROP) [44]. This study reports change in knowledge, attitude and practice of the ethno-veterinary practices (EVP) among farmers for selected animal health conditions and significant reduction of the antibiotic residue(s) in the milk after using cost effective ethno-veterinary medicine for prevention and cure of mastitis, foot and mouth disease (FMD), diarrhoea, udder pox, repeat breeding, bloat, indigestion and maggot wounds in cattle.

\section{Results}

\subsection{KAP analysis}

There is suggestive significance of change in knowledge and attitude about EVP, antibiotic residue in milk and AMR among the farmers from Kerala and Tamil Nadu. The study indicates strongly significant increase in the practices of EVP in this group and no significant change in KAP in EVP, antibiotic residue in the milk and AMR among farmers in Karnataka (Table: 1, 2 and 3). During the baseline many of the farmers were not aware that the milk from their cow could have antibiotic residue(s) and had no idea of AMR. They also believed that EVP may take long time to cure or will not be effective. There were limited skills for preparing the herbal formulations. The training had improved their skills for preparation and application of the herbal formulations

Table 1: Percentage change of total score of Baseline and End line scores on Knowledge, attitude and Practice (KAP) among farmers' on Ethno-veterinary Practices (EVP), antibiotic and veterinary drug residue in the milk (Kerala)

\begin{tabular}{|c|c|c|c|c|}
\hline$\%$ change of pre and post & $\begin{array}{c}\text { Intervention } \\
\text { Group } \\
(\mathrm{n}=78) \\
\end{array}$ & $\begin{array}{l}\text { Control } \\
\text { Group } \\
(n=63) \\
\end{array}$ & $\begin{array}{c}\text { Total } \\
(n=141)\end{array}$ & $P$ value \\
\hline \multicolumn{5}{|l|}{ Percentage Knowledge } \\
\hline $\begin{array}{l}\text { - Decreased/No } \\
\text { Change }\end{array}$ & $16(20.5 \%)$ & $24(38.1 \%)$ & $40(28.4 \%)$ & \multirow{5}{*}{$0.068+$} \\
\hline - $1-50$ & $52(66.7 \%)$ & $37(58.7 \%)$ & $89(63.1 \%)$ & \\
\hline - $51-75$ & $8(10.3 \%)$ & $2(3.2 \%)$ & $10(7.1 \%)$ & \\
\hline - $75-90$ & $1(1.3 \%)$ & $0(0 \%)$ & $1(0.7 \%)$ & \\
\hline - $>90$ & $1(1.3 \%)$ & $0(0 \%)$ & $1(0.7 \%)$ & \\
\hline
\end{tabular}

Percent Change Attitude 


\begin{tabular}{|c|c|c|c|c|}
\hline $\begin{array}{l}\text { - Decreased/No } \\
\text { Change }\end{array}$ & $23(29.5 \%)$ & $29(46 \%)$ & $52(36.9 \%)$ & \multirow{5}{*}{0.297} \\
\hline - $1-50$ & $43(55.1 \%)$ & $28(44.4 \%)$ & $71(50.4 \%)$ & \\
\hline - $51-75$ & $6(7.7 \%)$ & $2(3.2 \%)$ & $8(5.7 \%)$ & \\
\hline - $75-90$ & $2(2.6 \%)$ & $1(1.6 \%)$ & $3(2.1 \%)$ & \\
\hline - $>90$ & $4(5.1 \%)$ & $3(4.8 \%)$ & $7(5 \%)$ & \\
\hline \multicolumn{5}{|l|}{ Percent Change practice } \\
\hline $\begin{array}{l}\text { - Decreased/No } \\
\text { Change }\end{array}$ & $4(5.1 \%)$ & $29(46 \%)$ & $33(23.4 \%)$ & \multirow{5}{*}{$<0.001 * *$} \\
\hline - $1-50$ & $39(50 \%)$ & $24(38.1 \%)$ & $63(44.7 \%)$ & \\
\hline - $51-75$ & $19(24.4 \%)$ & $6(9.5 \%)$ & $25(17.7 \%)$ & \\
\hline - $75-90$ & $5(6.4 \%)$ & $0(0 \%)$ & $5(3.5 \%)$ & \\
\hline - $>90$ & $11(14.1 \%)$ & $4(6.3 \%)$ & $15(10.6 \%)$ & \\
\hline
\end{tabular}

\section{Chi-Square/Fisher Exact Test}

Table 2: Percentage change of total score of Baseline and End line scores on Knowledge, attitude and Practice (KAP) among farmer's on Ethno-veterinary Practices (EVP), antibiotic and veterinary drug residue in the milk (Karnataka)

\begin{tabular}{|c|c|c|c|c|}
\hline$\%$ change of pre and post & $\begin{array}{c}\text { Intervention } \\
\text { Group } \\
(\mathbf{n}=\mathbf{2 0})\end{array}$ & $\begin{array}{l}\text { Control } \\
\text { Group } \\
(n=18)\end{array}$ & $\begin{array}{c}\text { Total } \\
(n=38)\end{array}$ & $P$ value \\
\hline \multicolumn{5}{|l|}{ Percentage Knowledge } \\
\hline $\begin{array}{l}\text { - Decreased/No } \\
\text { Change }\end{array}$ & $9(45 \%)$ & $12(66.7 \%)$ & $21(55.3 \%)$ & \multirow{5}{*}{0.395} \\
\hline - $1-50$ & $10(50 \%)$ & $5(27.8 \%)$ & $15(39.5 \%)$ & \\
\hline - $51-75$ & $0(0 \%)$ & $0(0 \%)$ & $0(0 \%)$ & \\
\hline - $75-90$ & $0(0 \%)$ & $0(0 \%)$ & $0(0 \%)$ & \\
\hline - $\quad>90$ & $1(5 \%)$ & $1(5.6 \%)$ & $2(5.3 \%)$ & \\
\hline \multicolumn{5}{|l|}{ Percent Change Attitude } \\
\hline $\begin{array}{l}\text { - Decreased/No } \\
\text { Change }\end{array}$ & $10(50 \%)$ & $10(55.6 \%)$ & $20(52.6 \%)$ & \multirow{5}{*}{0.374} \\
\hline - $1-50$ & $7(35 \%)$ & $4(22.2 \%)$ & $11(28.9 \%)$ & \\
\hline - $51-75$ & $1(5 \%)$ & $4(22.2 \%)$ & $5(13.2 \%)$ & \\
\hline - $75-90$ & $1(5 \%)$ & $0(0 \%)$ & $1(2.6 \%)$ & \\
\hline - $>90$ & $1(5 \%)$ & $0(0 \%)$ & $1(2.6 \%)$ & \\
\hline
\end{tabular}




\begin{tabular}{|c|c|c|c|c|}
\hline \multicolumn{5}{|c|}{ Percent Change practice } \\
\hline $\begin{array}{l}\text { - Decreased/No } \\
\text { Change }\end{array}$ & $9(45 \%)$ & $7(38.9 \%)$ & $16(42.1 \%)$ & \multirow{5}{*}{0.917} \\
\hline - $1-50$ & $6(30 \%)$ & $8(44.4 \%)$ & $14(36.8 \%)$ & \\
\hline - $51-75$ & $2(10 \%)$ & $1(5.6 \%)$ & $3(7.9 \%)$ & \\
\hline - $75-90$ & $1(5 \%)$ & $1(5.6 \%)$ & $2(5.3 \%)$ & \\
\hline - $>90$ & $1(5 \%)$ & $1(5.6 \%)$ & $2(5.3 \%)$ & \\
\hline
\end{tabular}

\section{Chi-Square/Fisher Exact Test}

Table 3: Percentage change of total score of Baseline AND End line scores on Knowledge, attitude and Practice (KAP) among farmer's on Ethno-veterinary Practices (EVP), antibiotic and veterinary drug residue in the Milk (Tamil Nadu)

\begin{tabular}{|c|c|c|c|c|}
\hline $\begin{array}{c}\% \text { change of pre and } \\
\text { post }\end{array}$ & $\begin{array}{c}\text { Intervention } \\
\text { Group } \\
(\mathbf{n}=23)\end{array}$ & $\begin{array}{c}\text { Control } \\
\text { Group } \\
(\mathbf{n}=5)\end{array}$ & $\begin{array}{l}\text { Total } \\
(\mathrm{n}=28)\end{array}$ & $P$ value \\
\hline $\begin{array}{ll}\text { Percent } & \text { Change } \\
\text { Knowledge } & \\
\end{array}$ & & & & \\
\hline $\begin{array}{l}\text { - Decreased/No } \\
\text { Change }\end{array}$ & $6(26.1 \%)$ & $3(60 \%)$ & $9(32.1 \%)$ & \multirow{5}{*}{0.290} \\
\hline - $1-50$ & $17(73.9 \%)$ & $2(40 \%)$ & $19(67.9 \%)$ & \\
\hline - $51-75$ & $0(0 \%)$ & $0(0 \%)$ & $0(0 \%)$ & \\
\hline - $75-90$ & $0(0 \%)$ & $0(0 \%)$ & $0(0 \%)$ & \\
\hline - $\quad>90$ & $0(0 \%)$ & $0(0 \%)$ & $0(0 \%)$ & \\
\hline \multicolumn{5}{|l|}{ Percent Change Attitude } \\
\hline $\begin{array}{l}\text { - Decreased/No } \\
\text { Change }\end{array}$ & $7(30.4 \%)$ & $4(80 \%)$ & $11(39.3 \%)$ & \multirow{5}{*}{$0.062+$} \\
\hline - $1-50$ & $16(69.6 \%)$ & $1(20 \%)$ & $17(60.7 \%)$ & \\
\hline - $51-75$ & $0(0 \%)$ & $0(0 \%)$ & $0(0 \%)$ & \\
\hline - $75-90$ & $0(0 \%)$ & $0(0 \%)$ & $0(0 \%)$ & \\
\hline - $>90$ & $0(0 \%)$ & $0(0 \%)$ & $0(0 \%)$ & \\
\hline \multicolumn{5}{|l|}{ Percent Change practice } \\
\hline $\begin{array}{l}\text { - Decreased/No } \\
\text { Change }\end{array}$ & $3(13 \%)$ & $4(80 \%)$ & $7(25 \%)$ & \multirow{3}{*}{$0.008 * *$} \\
\hline - $1-50$ & $20(87 \%)$ & $1(20 \%)$ & $21(75 \%)$ & \\
\hline - $51-75$ & $0(0 \%)$ & $0(0 \%)$ & $0(0 \%)$ & \\
\hline
\end{tabular}




\begin{tabular}{llll}
\hline$-75-90$ & $0(0 \%)$ & $0(0 \%)$ & $0(0 \%)$ \\
\hline$\bullet>90$ & $0(0 \%)$ & $0(0 \%)$ & $0(0 \%)$ \\
\hline
\end{tabular}

Chi-Square/Fisher Exact Test

\section{Significant figures}

+ Suggestive significance $(\mathrm{P}$ value: $0.05<\mathrm{P}<0.10), *$ moderately significant $(\mathrm{P}$ value: $0.01<\mathrm{P} \leq 0.05)$, ** strongly significant $\quad(\mathrm{P}$ value: $\mathrm{P} \leq 0.01)$

\subsection{Antibiotic residue analysis of the Market samples}

Thirty five brands of milk sold in the Market were tested for presence of antibiotic residue. Twenty two had Beta lactams and Sulphonamides, 10 had only Sulphonamide. One brand had 4 antibiotics (Beta lactams, Sulphonamides, Gentamicin and Tetracycline) residues and 2 did not have any antibiotic residue (Table 4).

Table 4.Antibiotic residues in the Market Samples

\begin{tabular}{lllll}
\hline Market sample & $\begin{array}{l}\text { Beta lactam \& } \\
\text { Sulphonamide. }\end{array}$ & Sulphonamide & Gentamycin & Tetracycline \\
\hline 35 brands & 22 & 10 & 1 & 1 \\
\hline Codex & $\mathbf{0 - 3}$ PPB is & $\mathbf{0 - 1 0}$ PPB is negative & $\mathbf{0 - 5 0 ~ P P B ~ i s ~}$ & $\mathbf{0 - 8 0 P P B}$ \\
Alimentarius & negative & $\mathbf{1 5}$ PPB > Positive & negative & Negative \\
International & 4-10 PPB is & & $\mathbf{5 0 - 7 5 ~ P P B}$ & $\mathbf{8 0 - 1 0 0 ~ P P B}$ \\
food standard & positive & & Low Positive & Low Positive \\
(MRL) & & & $\mathbf{1 0 0 - 2 0 0}$ & $\mathbf{1 0 0 - 1 2 0 ~ P P B}$ \\
& & & PPB positive & Positive \\
\hline
\end{tabular}

\section{2 brands were without any antibiotic residues}

\subsection{Baseline}

The milk sample from 11 milk Union's collection centres had Quinolones, Beta lactams, Tetracycline and Sulphonamides as residues (Table 5). Gentamicin, Streptomycin, Neomycin and Chloramphenicol were absent. Quinolones, Beta lactams, Gentamicin, Sulphonamides were present as residues in the milk samples from farmers selected for the study except the milk from Thirukanurpatti, (Table 6). Tetracycline, Streptomycin, Neomycin, Chloramphenicol were absent.

Table 5.Antibiotics in the pooled Samples from the milk Union's collection centres ( $\mathrm{L}=$ Low positive)

\begin{tabular}{|c|c|c|c|c|}
\hline MILK Union & Quinolones & Beta lactams & Tetracycline & Sulfonamides \\
\hline Allapra & & Positive (L) & & \\
\hline Arakkapady & & Present & & Positive \\
\hline Chakkampuzha & & Positive & & \\
\hline Maneed & Positive & Positive & & \\
\hline Manikyamangalam & Positive (L) & Positive & & \\
\hline
\end{tabular}




\begin{tabular}{|c|c|c|c|}
\hline Monippally & & Positive & \\
\hline Puthrika & & Positive & \\
\hline Sreemoolanagaram & & Positive & Positive \\
\hline Thirukanurpatti & & Positive (L) & \\
\hline Aralumallige & P0sitive & Positive (L) & Positive \\
\hline Ekashipura & & positive & \\
\hline
\end{tabular}

Table 6: Antibiotics residue(s) in the milk of Pooled samples from the selected farmers' before intervention

\begin{tabular}{lllll}
\hline MILK Union & Quinolones & Beta lactams & Gentamicin & Sulfonamides \\
\hline Allapra & & Positive (L) & \\
\hline Arakkapady & & Positive & Positive \\
\hline Chakkampuzha & & Positive & \\
\hline Maneed & Positive & Positive & \\
\hline Manikyamangalam & & Positive (L) & \\
\hline Monippally & & Positive & \\
\hline Puthrika & Positive & Positive & \\
\hline Sreemoolanagaram & & Positive & \\
\hline Thirukanurpatti & & Negative & \\
\hline Aralumallige & Positive & Negative & Positive & \\
\hline Ekashipura & & Positive (L) & & \\
\hline (L= Low positive) & & & &
\end{tabular}

\subsection{End line survey}

The end line survey indicated that the milk samples from 123 farmers out of 140 (87.86\%) were without any detectable antibiotic residue(s), 11 (7.85\%) samples showed low positive of Beta lactams or sulphonamides and $6(4.29 \%)$ showed positive to antibiotic residue(s) of Beta lactams and or sulphonamides (Fig 1, table 7).

Fig 1.Antibiotic residue: Farmer Sample After one year intervention 


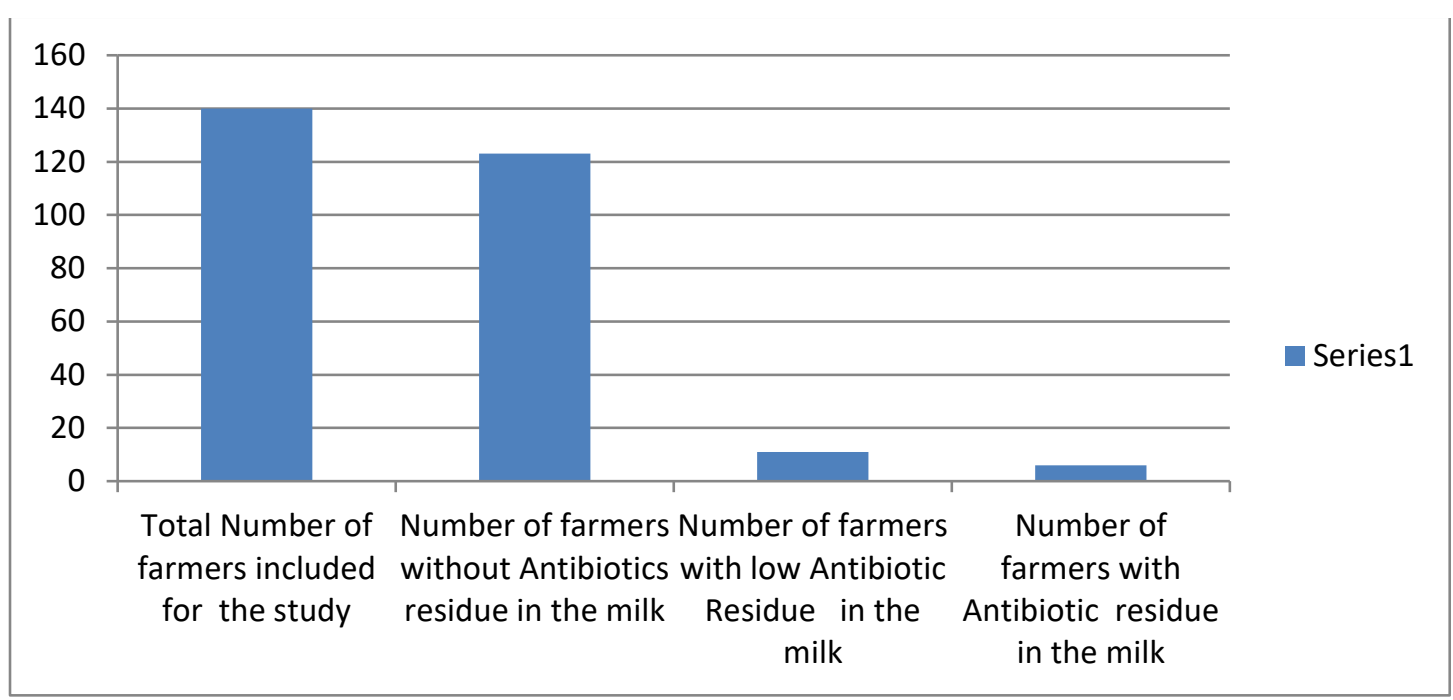

Table 7. Antibiotic residue: Farmer samples one year after intervention

\begin{tabular}{lllll}
\hline MILK Union & $\begin{array}{l}\text { Number } \\
\text { farmers }\end{array}$ & $\begin{array}{l}\text { Antimicrobial } \\
\text { Negative }\end{array}$ & $\begin{array}{l}\text { residue } \\
\text { Low } \\
\text { Positive }\end{array}$ & $\begin{array}{l}\text { Residue } \\
\text { Positive }\end{array}$ \\
\hline Allapra & 15 & 12 & 2 & 1 \\
\hline Arakkapady & 15 & 11 & 2 & 2 \\
\hline Chakkampuzha & 10 & 10 & 0 & 0 \\
\hline Maneed & 10 & 7 & 3 & 0 \\
\hline Manikyamangalam & 15 & 12 & 2 & 1 \\
\hline Monippally & 10 & 6 & 2 & 2 \\
\hline Puthrika & 10 & 10 & 0 & 0 \\
\hline Sreemoolanagaram & 15 & 15 & 0 & 0 \\
\hline Thirukanurpatti (TN) & 20 & 20 & 0 & 0 \\
\hline Aralumallige (Karn) & 20 & 20 & 0 & 0 \\
\hline & 140 & 123 & 11 & 6 \\
\hline Per cent & & $\mathbf{8 7 . 8 6 \%}$ & $\mathbf{7 . 8 5 \%}$ & $\mathbf{4 . 2 9 \%}$ \\
\hline
\end{tabular}

2.5. Reduction of incidence of disease conditions in cattle in the area selected for the studies when EVP is used

The incidence of mastitis was 66 in 2016, reduced to 37 in 2018 and to 11 in 2019 among the cows of farmers selected for the study. The overall reduction of mastitis from 2016 to 2019 is $83.3 \%$. There is also reduction in the incidence of enteritis (63.6\%), repeat breeding (96\%) and cowpox (100\%) from 2016 to 2019 (Table 8)

Table 8. Reduction of the incidence of Mastitis, Enteritis, repeat breeding and cow pox from 2016 to 2019 among the cows of the farmers selected for the study 


\begin{tabular}{llllllllllllll}
\hline Disease & \multicolumn{3}{c}{ Mastitis } & \multicolumn{3}{c}{ Enteritis } & \multicolumn{3}{c}{ Repeat breeding } & \multicolumn{3}{c}{ Cowpox } \\
\hline Year & 2016 & 2018 & 2019 & 2016 & 2018 & 2019 & 2016 & 2018 & 2019 & 2016 & 2018 & 2019 \\
\hline Average & 66 & 37 & 11 & 11 & 7 & 4 & 9 & 2.5 & 0.38 & 2.38 & 2.13 & 0 \\
\hline $\begin{array}{l}\text { Per cent } \\
\text { reduction }\end{array}$ & 44 & 83.3 & & 36.4 & 63.6 & & 72.2 & 95.8 & & 11 & 100 \\
\hline
\end{tabular}

\subsection{The control group}

The milk samples from control group had Beta lactams and/or sulphonamide (Table 9). Tetracycline, Streptomycin, Neomycin, Chloramphenicol Gentamicin were absent

Table 9: Antibiotics residue in the milk of Pooled samples from the control group after one year ( $\mathrm{L}=\mathrm{Low}$ positive)

\begin{tabular}{lll}
\hline MILK Union & Beta lactams & Sulfonamides \\
\hline Allapra & Positive & \\
\hline Arakkapady & Positive & Positive \\
\hline Chakkampuzha & Positive & \\
\hline Maneed & Positive & \\
\hline Manikyamangalam & Positive (L) & Positive \\
\hline Monippally & Positive & \\
\hline Puthrika & Positive (L) & \\
\hline Sreemoolanagaram & Positive & \\
\hline Thirukanurpatti & Negative & \\
\hline Aralumallige & Positive (L) & \\
\hline Ekashipura & Positive & \\
\hline
\end{tabular}

\subsection{Economic benefit of using Herbal formulation}

Average expenditure for treatment of mastitis with western medicine was Rs. 3000; maggot wound Rs.963, boat \& indigestion Rs.719, repeat breeding Rs.3061, cow pox Rs.583, foot and mouth disease (FMD) Rs. 3165, and diarrhoea Rs.500 per episode (Table 10). It is indicated that there is reduction of expenditure for the management of mastitis (Rs.3000 to 120), maggot wound (Rs. 963 to 60), bloat and indigestion (Rs.719 to 224), repeat breeding (Rs. 3061 to 430), cow pox (Rs. 583 to 335), FMD (Rs. 3165 to 1640) and diarrhoea (Rs. 500 to 166) with EVP.

Table 10: shows Average expenditure in Rupees for the treatment of various diseases in cattle using Western drugs (allopathic) and EVP (one episode) and the saving (1 USD = Rs.73.52 on 01/12/ 2020)

\begin{tabular}{llllll} 
No & Disease conditions & n & $\begin{array}{l}\text { western } \\
\text { drug } \\
\text { treatment }\end{array}$ & $\begin{array}{l}\text { EVP } \\
\text { treatment }\end{array}$ & $\begin{array}{l}\text { Amount } \\
\text { saved }\end{array}$ \\
1. & Mastitis & 35 & 3000 & 120 & 2880 \\
\cline { 2 - 6 } 2. & Maggot wound & 28 & 962.5 & 60 & 881.7 \\
\cline { 2 - 6 } 3. & Bloat\& Indigestion & 34 & 719.4 & 224 & 495.4 \\
\cline { 2 - 6 }
\end{tabular}




\begin{tabular}{llllll}
\hline 4. & Repeat breeding & 23 & 3060.7 & 430 & 2630.9 \\
\cline { 2 - 5 } 5. & Cow pox & 18 & 583.3 & 335 & 250 \\
\cline { 2 - 5 } 6. & Foot and Mouth Disease (FMD) & 22 & 3165 & 1640 & 1525 \\
\cline { 2 - 5 } 7. & Diarrhea & 3 & 500 & 166 & 334 \\
\cline { 2 - 5 }
\end{tabular}

\subsection{Production loss}

The average milk production loss was 15 to 22.2 litres for 6 days when treated with western medicines. The details are given in the table 11. However, the loss is only 0.2 to 0.5 litres when treated with EVP (Table 12). In the case of FMD there is no loss but sometimes there is an increase of production by 0.7 litres

Table 11. Shows the loss of milk in litters when treated with western (allopathic) drugs (1 USD = Rs.73.52 on $01 / 12 / 2020$ )

\begin{tabular}{lcccccc}
\hline Disease conditions & n & $\begin{array}{l}\text { Before } \\
\text { treatment }\end{array}$ & $\begin{array}{l}\text { After } \\
\text { treatment }\end{array}$ & $\begin{array}{l}\text { Loss of milk } \\
\text { In liters } \\
\text { day }\end{array}$ & $\begin{array}{l}\text { Loss for 6 } \\
\text { days in }\end{array}$ & $\begin{array}{l}\text { Financial } \\
\text { loss in Rs }\end{array}$ \\
\hline Mastitis & 35 & 12.8 & 10.5 & 2.5 & 15.0 & 390 \\
\hline Maggot wound & 28 & 13.1 & 10.6 & 2.5 & 15.0 & 390 \\
\hline Bloat\& Indigestion & 34 & 14.0 & 10.5 & 3.5 & 21.0 & 546 \\
\hline Repeat breeding & 23 & 16.0 & 13.2 & 2.8 & 16.8 & 437 \\
\hline Cow pox & 18 & 14.9 & 11.8 & 3.1 & 18.6 & 484 \\
\hline FMD & 22 & 9.71 & 06.0 & 3.7 & 22.2 & 577 \\
\hline (Rs 26 per litre of milk - procurement cost)
\end{tabular}

Table 12 shows the average loss of milk in litres and financial loss before and after treatment of diseases in cattle with EVP (1 USD = Rs.73.52 on 01/12/ 2020)

\begin{tabular}{|c|c|c|c|c|c|c|}
\hline No & $\begin{array}{l}\text { Disease } \\
\text { conditions }\end{array}$ & $\mathbf{n}$ & $\begin{array}{l}\text { Before } \\
\text { treatment }\end{array}$ & $\begin{array}{l}\text { After } \\
\text { treatment }\end{array}$ & $\begin{array}{l}\text { Loss of milk } \\
\text { in } 6 \text { days in } \\
\text { liters }\end{array}$ & $\begin{array}{l}\text { Financial } \\
\text { loss in Rs }\end{array}$ \\
\hline 1 & Mastitis & 35 & 14.4 & 14 & 0.4 & 10 \\
\hline 2 & Maggot wound & 28 & 13.7 & 13.3 & 0.4 & 10 \\
\hline 3 & Bloat\& Indigestion & 34 & 14 & 14 & Nil & Nil \\
\hline 4 & Repeat breeding & 23 & 15 & 14.8 & 0.2 & 5 \\
\hline 5 & Cow pox & 18 & 15.6 & 15.1 & 0.5 & 13 \\
\hline 6 & FMD & 22 & 10.3 & 11. & -0.7 & +18 \\
\hline
\end{tabular}

Total 5.5 Liters gain, average. ( Rs 26 per liter) 


\section{Discussion}

This study shows that veterinarians, farmers and para-vets are using antibiotics and there is antibiotic residue in the milk [1-12]. This indicates that farmers/veterinarians do not practice health ministry's withdrawal time [2, 11, 13, 14, 15 and 20]. The rule states that the antibiotics used for therapeutic purpose in animals should be labeled with the withdrawal periods i.e. "milk and eggs should be kept out of human food minimum for one week, poultry and meat products 28 days, fish and other marine products 500 degree days" (Health ministry: withdrawal time. the amendment in rule 97 of the drug and cosmetic rules 1947). The baseline survey of the farmers indicates that the farmers were not aware about this rule and their cows' milk could have antibiotic residue(s). They were also ignorant about the AMR. All 200 milk samples collected from collection centres before the intervention tested positive for one or the other antibiotic residue. The farmers / Veterinarians from Thirukanurpatti also use antibiotic however, during the period when the milk samples were collected, probably there were no clinical conditions needing antibiotic treatment.

\subsection{The intervention}

The herbal formulations used for Mastitis, Foot and mouth disease (FMD), Diarrhoea, Udder Pox, Repeat Breeding, Bloat, Indigestion and Maggot wound, not only cure these clinical conditions but also prevent these diseases. This is evident from the substantial reduction of incidence of mastitis (83.8\%), enteritis $(63.6 \%)$ repeat breeding $(95.8 \%)$ and udder pox $(100 \%)$. The reduction of antibiotic residue is significant $(87.86 \%)$. There is limited number of such studies done on the role of EVP (herbal formulation) in animal health conditions. $[14,15,39-44]$. The residue in the milk from the control group after one year is largely Beta lactams and sometimes Sulphonamides indicating the widespread use of these groups of antibiotics. This intervention also has increased the knowledge, aptitude and practice among the farmers and awareness about the antimicrobial residue in the animal products and associated antimicrobial resistance.

\subsection{Economic benefit}

Misuse of the drug, non-adherence to withdrawal period, economic reasons, ignorance, lack of medication records are the major reasons of appearance of veterinary drug residues in the animal products [45-47]. The combination of improved management practices with the use of herbal formulation in animal health care evidently is cost effective. It also minimised the production loss and improved quality of dairy milk. This work also indicates the reduction of use of antimicrobials for management of cattle health and their residue in the milk. This is a step towards renewed interest in ethno-veterinary practices (herbal alternatives) among the national dairy development of India initiatives and enterprises, which face the problems related to antimicrobial residue in the dairy milk due to misuse of antibiotics.

\section{Material and Methods}

Two hundred twenty farmers were selected from eight milk societies from Kerala state, two societies in Karnataka and one in Tamil Nadu. The names of the selected milk societies and number of farmers selected for the study are given in table 13. One forty farmers were included in the intervention study group and 80 
in the control group.

Table 13 Show the name of the milk society, number of farmers selected as interventions and controls group

\begin{tabular}{|c|c|c|c|c|}
\hline No & Name of the society & $\begin{array}{l}\text { Number } \\
\text { Farmers } \\
\text { selected }\end{array}$ & $\begin{array}{l}\text { Intervention } \\
\text { group }\end{array}$ & $\begin{array}{l}\text { Control } \\
\text { Group }\end{array}$ \\
\hline 1 & $\begin{array}{l}\text { Maneed KheeraUlpadaka Society } \\
\text { Ernakulam Kerala }\end{array}$ & 20 & 10 & 10 \\
\hline 2 & $\begin{array}{l}\text { Monippally KheeraUlpadaka } \\
\text { Society. Kottayam, Kerala }\end{array}$ & 20 & 10 & 10 \\
\hline 3 & $\begin{array}{l}\text { ChakkampuzhaKheeraUlpadaka } \\
\text { Society Kottayam Kerala }\end{array}$ & 20 & 10 & 10 \\
\hline 4 & $\begin{array}{l}\text { PuthrikaKheeraUlpadaka Society } \\
\text { Ernakulan Kerala }\end{array}$ & 20 & 10 & 10 \\
\hline 5 & $\begin{array}{l}\text { Allappara KheeraUlpadaka Society } \\
\text { Ernakulan Kerala }\end{array}$ & 15 & 15 & 0 \\
\hline 6 & $\begin{array}{l}\text { Arakkappadi KheeraUlpadaka } \\
\text { Society, Ernakulan Kerala }\end{array}$ & 15 & 15 & 0 \\
\hline 7 & $\begin{array}{l}\text { Manikyamangalam Kheera } \\
\text { Ulpadaka Society Ernakulan Kerala. }\end{array}$ & 15 & 15 & 0 \\
\hline 8 & $\begin{array}{l}\text { Sreemoolanagaram Kheera } \\
\text { Ulpadaka Society Ernakulan, Kerala }\end{array}$ & 15 & 15 & 0 \\
\hline 9 & $\begin{array}{l}\text { Thirukanurpatti, Thanjavur Tamil } \\
\text { Nadu }\end{array}$ & 40 & 20 & 20 \\
\hline 10 & $\begin{array}{l}\text { Aralumallige, Doddaballapura, } \\
\text { Karnataka }\end{array}$ & 20 & 20 & 0 \\
\hline \multirow[t]{2}{*}{11} & $\begin{array}{l}\text { Ekashipura, Doddaballapura, } \\
\text { Karnataka }\end{array}$ & 20 & 0 & 20 \\
\hline & Total & 220 & 140 & 80 \\
\hline
\end{tabular}

Knowledge, attitude, and practice (KAP) survey of Ethno-veterinary practices (EVP) among the selected farmers, were undertaken. The baseline and end line surveys were conducted using a format with 1 to 10 scales and personal interview.

Thirty five market samples in triplicate were collected and tested for the presence of antibiotic residue(s). The pooled milk samples from 11 milk union collection centres and 220 farmers before and after intervention were tested for the presence of antibiotic residue(s) using Unisensor (Belgium).

The 140 farmers from 11 unions (intervention group) who consented to use only EVP and not antibiotics, were trained to use validated EVP for Mastitis, Foot and mouth disease (FMD), Diarrhoea, Udder Pox, Repeat Breeding, Bloat, Indigestion and Maggot wounds repeatedly for one year. The treatment protocols by 
farmers were monitored randomly. The field support was given whenever it was necessary. Hand books were printed in local languages (Kannada, Malayalam and Tamil) and distributed to the selected farmers for reference.

\section{Conclusion}

The use of herbal preparation as alternatives to antimicrobials shows significant reduction in the antibiotic residues in the milk from cattle and increased financial saving for the farmers. Adopting the Ethno-veterinary Science and Practices to combat infectious diseases in livestock has been identified and tested as a key game changer in rationalising the use of antibiotics in veterinary health care and reducing antibiotic residue(s) in milk.

\section{Acknowledgement}

We acknowledge Department of Science and Technology Government of India (DST GOI SEEDS project) for financial support for this work. We also thank MILMA, BAMUL and AAVIN and all employs of the Union collection centres and farmers for their cooperation to conduct this study. We express our sincere appreciation to the Mr. Narayana Kaimal of KCT, Chakkampuzha, Mr Abhilash Raju, Mrs Anitha Nagaraj and Aditye Nair for the help during the field study. Our thanks to Dr K P Suresh from NIVEDI for the statistical analysis

\section{Author Contributions}

Field study at Kerala conducted by M N B Nair, Tamil Nadu by N Punniamurthy and Karnataka by Kumar SK and all authors approved the final version of the manuscript.

\section{Author Biography}

8.1. DR. Balakrishnan Mannoor Narayanan Nair is working as Professor Emeritus and Head of Centre for Ethno-veterinary sciences and Practice at the University of trans-disciplinary health sciences and technology (TDU). He has BSc and MSc in Botany, and Ph. D. in developmental anatomy. Nair has 39 years of teaching and research experience, over 45 publications and contributed to different books. His Research interests are trans-disciplinary research, one health, documentation of ethno-veterinary practices, validation and promotion of them through mainstreaming in veterinary curriculum, training of vets, farmers and Dairy professionals to reduce antimicrobial use in dairy production and associated residues in the animal products. He has expertise in wood structure and natural gum and gum-resin secretion, their sustainable tapping and uses. He is a life member of Indian Botanical society, Tree scientist, International Association of wood Anatomists, Executive Board member of Natural Livestock Faming, Netherlands and Director NLF India.

8.2. Dr Natesan Punniamurthy is currently Professor-Emeritus of TDU Bangalore, India, had BVSC, MVSc PhD from Madras Veterinary College, India. As professor of Pharmacology and Toxicology he taught UG, PG veterinary-students for 12 years. Has 40 years' experience in teaching, research, extension in TANUVAS/TDU. He has worked in neuropharmacology of feeding behaviour. He has 20 years research 
experience in documentation and validating veterinary clinical-herbal-medicine; currently train veterinarians across India and mainstreaming EVP in veterinary curriculum. Gold medal in PhD 1995, Life Member "Indian Veterinary Association", Achiever award IVA 2019. Fellow "National society for Ethno pharmacology" 2017, Fellow "Indian Society for Veterinary pharmacology and Toxicology" 2016, Lifetime Achievement Award for promoting Siddha medicine, Government Siddha Medical College, Tamil Nadu 2014, Tamil Nadu Scientist award by State Council for Science and Technology for decade of research accomplishments in EVM, 2013, Achievement award for EVM recipes dissemination, Thamizhar Vazhviyal Iyakkam, 2005 from Nammazhlwar.

8.3. Dr Kumar Seethakempanahalli Kempanna is working as Scientist E. at Centre for Ethno-veterinary Science and Practice, the University of University of trans-disciplinary health sciences and technology (TDU). He has Bachelors of Ayurveda Medicine and Surgery (BAMS), Masters in Ayurveda (MD) at Govt. Ayurveda Medical College. He also completed Post graduate diploma in Clinical research (Institute of Clinical Research India and Post graduate diploma in One Health (Kerala Veterinary \& Animal Sciences University). He has 15 Years of experience as an Ayurveda physician. He has experience in drug standardization, development of Ayurveda formulation for clinical application, documentation, assessment and promotion of ethno-veterinary practices, and development of curriculum for post graduate diploma and certificate programme in Ethno veterinary Practices. His interests are in Anti-Microbial Resistance (AMR), Antimicrobial residues, Alternatives for Antibiotics, One Health and Veterinary Ayurveda

\section{Conflicts of Interest}

The authors declare that they have no Conflicts of Interest.

\section{Reference}

1. Asif, M.H.; Latha, C.; Vrinda Menon K.; Deepa Jolly; Suresh, N. Nair.; Sunanda, C. The occurrence of antibiotic residues in pooled raw cow milk samples of Palakkad, Kerala. J. Vet. Anim. Sci. 2020, 51 (1): 34 - 39.

2. Kumaraswamy, N. P.; Latha, C.; Vinda, K. Menon; Sethulakshmi, C.; Mary, K. A. Detection of antibiotic residue in raw cow milk in Thrissur, India. The Pharma Innovation J.2018 (8): 452-454.

3. Pallavi Moudgil, Jasbir Singh Bedi, Rabinder Singh Aulakh \& Jatinder Paul Singh Gill Antibiotic residues and mycotoxins in raw milk in Punjab (India): a rising concern for food safety $\underline{\text { J. Food Science }}$ and Technol. 2019, 56, 5146-5151. (Abstract)

https://link.springer.com/article/10.1007/s13197-019-03963-8?shared-article-renderer (accessed 15 Dec. 2020).

4. Leandro da Conceicao Luiz; Maria Jose Valenzuela Bell; Roney Alves da Rocha;Nayara Lizandra Leal;Virgilio de Carvalho dosAnjos. Detection of veterinary Antimicrobial Residues in milk through Near-infrared Absorption Spectroscopy. J. Spectroscopy, 6, Article ID 5152832https://doi.org/10.1155/2018/5152832

https://www.hindawi.com/journals/jspec/2018/5152832/ (accessed 15 Dec. 2020)

5. uFFooDS Spectrum, 24, July, 2019.

https://www.nuffoodsspectrum.in/news/31/5369/antibiotic-residues-in-milk-put-indian-igen-at(accessed 15 Dec. 2020).

6. Sumanth Gandra; Jyoti Joshi; Anna Trett; Anjana Sankhil Lamkang; Ramanan 
Laxminarayan. Scoping Report on Antimicrobial Resistance in India. 2017

Washington, DC: Center for Disease Dynamics, Economics \& Policy.

7. Moharana, B; Venkatesh, P.K.; Preetha, S.P.; Selvasubramanian, S. () Quantification of enrofloxacin residues in milk sample using RP-HPLC. World J Pharm Pharm Sci. 2015, 4:1443

8. Ram, C.; Bhavadasan, M.K.; Vijaya, G.V. Antibiotic residues in milk. Indian J. Dairy and Biosci. 2000; 11(5): 151-154.

9. Priyanka ; Sumitra Panigrahi; Maninder Singh Sheoran; Subha Ganguly. Antibiotic residues in milk- a serious public health hazard Review Article. J. Environ. Life Sci. 2017; Vol. 2 (4): 99-102.

www.imedpharm.com/journals/index.php/jels

10. Sudershan, R.V.; Bhat, R.V.A survey on veterinary drug use and residues in the milk in Hyderabad. Food.Addit. contam. 1995, 12; 654-650.

11. Dinki, N.; Balcha, E. Detection of antibiotic residues and determination of microbial quality of milk from milk collection canters. Adv.Anim Ve. Sci.2013: 1 (30);80-83.

12. Gaurav, A.; Gill, J.P.S.; Aulakh, R.S.; Bedi, J.S. ELISA based monitoring and analysis of tetracycline residues in cattle milk in various districts of Punjab. Vetinary World. 2014; 7(1): 26-29.

13. Jeena, S.; Venkateswaramurthy, N.; Sambathkumar, R. Antibiotic Residues in Milk Products: Impacts on Human Health. Res. J. Pharmacology and Pharmacodynamics.2020; 12(1):15-20. doi: 10.5958/2321-5836.2020.00004.X

14. Vishnuraj MR, Kandeepan G, Rao KH, Chand S, Kumbhar V. Occurrence, public health hazards and detection methods of antibiotic residues in foods of animal origin: A comprehensive review. Cogent Food and Agriculture. 2016; 2(1): 123-126. DOI: $10.1080 / 23311932.2016 .1235458$

15. Prajwal, S.; Vasudevan, V.N.; Sathu, T.; Irshad, A.; Nayankumar, S.R.; Kuleswan Pame. Antibiotic residues in food animals: Causes and health effects. The Pharma Innovation J. 2017; 6(12): 01-04 https://www.thepharmajournal.com/archives/2017/vol6issue12/PartA/6-11-134-234.pdf (Accessed Dec, 15, 2020)

16. Nisha, A.R. Antibiotic residues-A global health hazard. Vet World. 2008; 1:375-377. http://dx.doi.org/10.5455/vetworld.2008.375-377 (Accessed Dec, 15, 2020)

17. Thomas ,P.; Van Boeckel; Charles Brower; Marius Gilbert; Bryyan, T.; Grenfell, Simon A.; Tmothy, P.; Robinson, Aude Teillant; Ramanan Laxminarayanan. Global trends in antimicrobial use in food animals; PNAS May 5, 2015; 112 (18) 5649-5654, https://doi.org/10.1073/pnas.1503141112. https://doi.org/10.1073/pnas.1503141112

18. Laura, J.; Shallcross, Simon; J. Howard, Tom Fowler Sally; Davies, C. Tackling the threat of antimicrobial resistance: from policy to sustainable action. Philos Trans R Soc Lond B Biol Sci. 2015 Jun 5; 370(1670): 20140082. doi: 10.1098/rstb.2014.0082

19. Eili, Y. Klein; Thomas, P.; Van Boeckel; Elena, M.; Martinez; Suraj Pant; Sumanth Gandra; Simon, A.; Levin; Herman Goossens; Ramanan Laxminarayan. Global increase and geographic convergence in antibiotic consumption between 2000 and 2015, PNAS April 10, 2018, 115 (15), E3463-E3470; https://doi.org/10.1073/pnas.1717295115

20. Florence Mutua; Garima Sharma; Delia Grace; Samiran Bandyopadhyay; Bibek Shome; Johanna Lindahl. A review of animal health and drug use practices in India, and their possible link to antimicrobial resistance, Antimicrobial Resistance \& Infection Control volume 9, Article number: 103Published: 08 July 2020 https://aricjournal.biomedcentral.com/articles/10.1186/s13756-020-00760-3

21. The Review on Antimicrobial Resistance, chaired by Jim O’Neill. Antimicrobial Resistance: Tackling a crisis for the health and wealth of nations. Dec 2014.

https://amr-review.org/sites/default/files/AMR\%20Review\%20Paper\%20-\%20Tackling\%20a\%20crisis\%20for\%20th e\%20health\%20and\%20wealth\%20of\%20nations 1.pdf 
22. Nair, M.N.B; Unnikrishnan, P.M. Ethno-veterinary Botanical Medicine-Herbal Medicine for Animal Health. Katerere DR, Luseba D (eds.) CRC-Press, Taylor \& Francis group, USA. 2010, 95-124.

23. Bandyopadhyay, S.; Mukherjee, S.K. Ethno-veterinary medicine from Koch Bihar district, West Bengal. Indian J Tradit Knowle., 2005, 4(4),456-461.

24. Deshmukh, R.R.; Rathod, V.N.; Pardeshi, V.N. Ethno-veterinary medicine from Jalna district of Maharashtra state. Indian J Tradit Knowle., 2011,10(2), 344-348.

25. Dey, A.; De, J.N. Ethno-veterinary uses of medicinal plants by the aboriginals of Purulia district, West Bengal, India, Int J Bot. 2010, 6, 433-440.

26. Deshmukh, R.R.; Rathod, V.N.; Pardeshi, V.N. Ethno-veterinary Medicine from Jalna District of Maharashtra State. Indian J. Tradit. Knowle. 2011, 10(2), 344-348.

27. Gaur, R.D.; Sharma, J.; Painuli, R.M. Plants used in traditional healthcare of livestock by Gujjar community of Sub- Himalayan tracts, Uttarakhand, India, Indian J Nat Prod Resour. 2010, 1(2),243-248.

28. Ghosh, A. Herbal veterinary medicine from the tribal areas of Bankura district, West Bengal, J Econ Taxon Bot. 1999, 23,557-560.

29. Mallik, B.K.; Panda, T.; Padhy, R.N. Ethno-veterinary Practices of Aborigine Tribes in Odisha, India. Asian Pac. J Trop. Biomed. Magazine. 2012, 2(3),1520-1525.

30. Mistry, N.; Silori, C.S.; Gupta, L.; Dixit, A.M. Indigenous knowledge on animal healthcare practices in district Kachchh, Gujarat. Indian J. Tradit. Knowle. 2003, 2(3), 240-254.

31. Phondani, P.C.; Maikhuri, R.K.; Kala, C.P. Ethno-veterinary uses of medicinal plants among traditional herbal healers in Alaknanda catchment of Uttarakhand, India, Afr J Tradit Compl Altern Med., 2010, 7(3),195-206.

32. Rajakumar N, Shivanna MB. Traditional veterinary healthcare practices in Shimoga district of Karnataka, India, Indian J Tradit Knowle. 2012; 11(2):283-287.

33. Sharma, A.; Santvan, V. K.; Sharma, P.; Chandel. S. "Ethno-veterinary Practices in Jawalamukhi, Himachal Pradesh, India". Int. Res. J. Biological Sci, 2014, 3(10), 6-12. http://updatepublishing.com/journal/index.php/ripb/article/view/2614

34. Bhatt, P. R.; Kajal, B. Pandya; Patel, U. D.; Patel, H. B.; Modi, C. M. Survey on Ethnoveterinary Practices around Junagadh, Gujarat, India, Indian J. Pharm Sci., 2019, 81(1), 161-167.

35. Swaminathan Usha; Chandrasekaran Rajasekaran; Ramamoorthy Siva. Ethno-veterinary medicine of the Shervaroy Hills of Eastern Ghats, India as alternative medicine for animals. J. Traditional and complementary medicine, 2016, 6 (1). 118-125. https://doi.org/10.1016/j.jtcme.2014.11.013

36. Sri Balaji, N.; Vikrama Chakravarthi, P. Ethno-veterinary Practices in India - A Review; Veterinary World, 2010, 3(12), 549-551.

37. Phondani, P. C.; Maikhuri, R. K.; Kala, C. P. Ethno-veterinary Uses of Medicinal Plants Among Traditional Herbal Healers in Alaknanda Catchment of Uttarakhand, India; Afr. J. Tradit. Complement Altern. Med., 2010, 7(3), 195-206. doi: 10.4314/ajtcam.v7i3.54775. https://www.ncbi.nlm.nih.gov/pmc/articles/PMC3025619/

38. Subhasree Pradhan; Suryakanta Mishra. Ethno-veterinary practice: An alternative treatment approach in contemporary India. The Pharma Innovation J. 2018, 7(9), 362-365

39. Nair, M. N. B.; Punniamurthy, N.; Kumar, S. K. Ethno-veterinary practices and the associated medicinal plants from 24 locations in 10 states of India. RRJVS/J. Vet.Sci. 2017, 3 (2), 16-25.

40. Punniamurthy, N.; Ramakrishnan, N.; Nair, M.N.B.; Vijayaraghavan, S. In-Vitro Antimicrobial Activity of Ethno-veterinary Herbal Preparation for Mastitis. Dairy and Vet Sci. J., 2017, 3(2), 555607. DOI: 
41. Nair, M. N. B.; Punniamurthy, N.; Mekala, P.; Ramakrishnan, N.; Kumar, S.K. Ethno-veterinary Formulation for Treatment of Bovine Mastitis, RRJVS/ J. Vet.Sci.2017. S1. 25-29

42. Punniamurthy,N.; Sujatha, P. L.; Preetha, S. P.; Ramakrishnan, N. Analysis of the mechanism of action by molecular docking studies of one ethno-veterinary herbal preparation used in bovine mastitis IJANS. 2017, 6, (5), 23-30. ISSN(P): 2319-4014; ISSN(E): 2319-4022

43. Kumar, S. K.; Deepa, P. M.; Punnimurthy, N.; Nair, M.N.B. Prevention of mastitis in cattle during dry period using herbal formulation. RRJVS, 2018, 4 (1), e-ISSN:2581-3897

44. Suresh, B.; Puniamurthy, N.; Nair, M.N.B. Dhanwantharam Kashayam for Preventing Post-Partum Complications in Cross-Bred Cows. Dairy and Vet Sci J. 2018; 5(4): 555666. DOI: 10.19080/JDVS.2018.05.555666004

45. Halasa, T.; Huijps, K.; Østerås, O.; Hogeveen, H. () Economic effects of bovine mastitis and mastitis management: A review, Veterinary Quarterly, 2007, 29(1), 18-31, DOI: 10.1080/01652176.2007.9695224 https://doi.org/10.1080/01652176.2007.9695224

46. Shim, E. H.; Shanks, R. D.; Morin, D. E. Milk Loss and Treatment Costs Associated with Two Treatment Protocols for Clinical Mastitis in Dairy Cows, J. Dairy Sci., 2004, 87:2702-2708

47. Shim, E. H. Milk Production Loss Associated with Clinical Mastitis and the Efficacy of Treatment Protocols. M.S. Thesis. 2001, University of Illinois, Urbana. 